\title{
On the Need for Digital Phenotyping to Obtain Insights into Mental States in the COVID-19 Pandemic
}

\author{
Christian Montag ${ }^{1 *}$, Paul Dagum² \& Jon D. Elhai ${ }^{3,4}$ \\ ${ }^{1}$ Department of Molecular Psychology, Institute of Psychology and Education, Ulm University, Ulm, Germany \\ 2 Applied Cognition, Los Altos, CA, USA \\ ${ }^{3}$ Department of Psychology, University of Toledo, Toledo, OH, USA \\ ${ }^{4}$ Department of Psychiatry, University of Toledo, Toledo, OH, USA
}

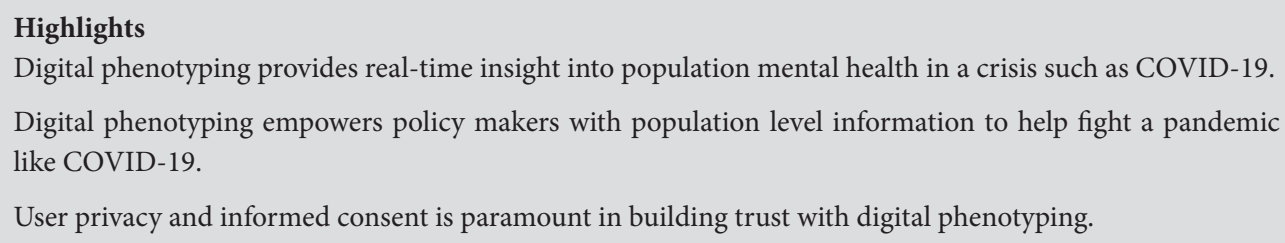

Letter History

Received 21 May 2020

Revised 26 May 2020

Accepted 26 May 2020

DOI 10.24989/dp.v1i2.1857
Coronavirus Disease 2019 (COVID-19) has caused a worldwide pandemic. Respiratory failure is among the most common causes of death related to COVID-19 (Mehta et al., 2020). Beyond the current debate on developing vaccines and appropriate treatments for COVID-19 (Lurie et al., 2020; Matthay et al., 2020), discussions have emerged on how the pandemic can be successfully controlled by technological means (Mayor, 2020; McCall, 2020). Beyond the widespread recommendations to control the virus by washing hands regularly, wearing respiratory masks, and practicing social distancing (perhaps more appropriately called physical distancing because it is also possible to socially interact virtually; for effects of travel restrictions see (Matthay et al., 2020)), there is interest in using mobile phone data to better understand how COVID-19 spreads in a given population (Oliver et al., 2020).

Various tracking technologies have been proposed, with different levels of privacy issues (Cho et al., 2020; Ienca \& Vayena, 2020). Perhaps the least invasive method to track the spread of COVID-19 uses Bluetooth technology, where one's smartphone logs the identity of other smartphone users with whom the person interacted for specific periods of time (Abeler et al., 2020). The data are stored on the smartphone and are only transferred to a server if the user decides to share this information, for example if they learn that they have been infected. This approach is expected to be effective only if a minimum of $60 \%$ of a population install such an application (Hurtz, 2020). Current statistics from countries such as Austria (3\%) and Singapore (20\%) show that typically the minimum threshold is not reached (Rosenbach et al., 2020), perhaps due to privacy concerns.

Beyond the question of whether smartphone-tracking procedures can adequately minimize the spread of COVID-19 in a population, use of smartphone tracking might have additional benefits in the context of a pandemic. The data derived from smartphones can be used to obtain insights on changes in psychological variables, such as the current mental state of a person, that are induced by a pandemic (Baumeister \& Montag, 2019; Dagum, 2018). For instance, smartphone call behavior is robustly associated with extraversion (Montag et al., 2014, 2019). Detecting psychological states and traits from digital traces logged on smartphones and other connected devices is called digital phenotyping (Insel, 2017, 2018). It has shown promise in longitudinally assessing affective states (Messner et al., 2019; Zulueta et al., 2018), including providing insights into affective disorders such as major depression (Saeb et al., 2015, 2017). In principle, app tracking technologies could be used to track the spread of COVID-19 and further assess its adverse effects. For example, such tracking could be used to assess the increase of mental disorders that are a consequence of the effects of the COVID-19 pandemic. This includes the effects of loneliness and social isolation (Armitage \& Nellums, 2020), and concerns about job losses and related financial duress (Coibion et al., 2020). At the moment it is difficult to obtain insights into the potential rise of mental disorders related to COVID-19. Social distancing prevents many people from obtaining access to mental health professionals. Digital phenotyping via smartphone tracking tech- 
nologies could help reveal those who may benefit from access to health support and services.

Insight into population mental health in the COVID-19 pandemic is relevant to policy makers whose decisions on restricting social interactions, closing economic sectors, and imposing selfquarantine measures, need to reflect the indirect societal costs and health implications of depression and addiction. In this domain, Schimmenti et al. identified four areas, which might be among the causal factors for psychiatric disorders triggered by COVID-19. Here, the authors discuss the components: "(1) fear of the body/fear for the body, (2) fear of significant others/fear for significant others, (3) fear of not knowing/fear of knowing, and (4) fear of taking action/fear of inaction" (Schimmenti et al., 2020. p. 41).

The negative psychological impact of COVID-19, including adverse effects directly attributable to COVID-19 itself, and also indirect effects due to isolation or heightened anxiety/fear from constant media coverage, has already received empirical support in the literature. A nationwide survey from China reported that approximately $35 \%$ of the investigated population showed signs of significant psychological distress (Qiu et al., 2020). In Iran it has been reported that fear of COVID-19 correlates with elevated depression and anxiety symptoms (Ahorsu et al., 2020), and in Bangladesh the first case of suicide (of a 36 year old man) due to fear of infection by COVID-19 has been recorded (Mamun \& Griffiths, 2020). COVID-19 could result in a higher risk of increased alcohol use disorders over time (Clay \& Parker, 2020). In March 2020, Germans bought 12\% more beer and 31\% more high alcohol-content drinks compared to the same period the year before (Bartel, 2020). Such elevated alcohol consumption could be a consequence of isolation and/or fear of COVID-19. A recent paper also discussed the potential negative consequences of COVID-19 in the area of problematic Internet use, in the context of prolonged screen time sessions that are a result of governmental requests to stay at home (Király et al., 2020).

We need to pay greater attention to the negative mental health and social implications of the COVID-19 crisis and related policies. Population scale digital phenotyping can provide important insights on changes in population mental health and the impact of government policy. We must balance this potential benefit with ethical issues arising from the use of tracking technologies, perhaps the most problematic being privacy violations in the age of surveillance capitalism (Dagum \& Montag, 2019; Martinez-Martin et al., 2018; Montag et al., 2020; Zuboff, 2019). Therefore, we stress the importance of protecting personal privacy while developing tracking solutions that can provide authorities with real time information on mental health in large populations during the COVID-19 pandemic.

\section{References}

Abeler, J., Bäcker, M., Buermeyer, U., \& Zillessen, H. (2020). COVID-19 Contact Tracing and Data Protection Can Go Together. JMIR MHealth and UHealth, 8(4), e19359. https://doi.org/10.2196/19359
Ahorsu, D. K., Lin, C.-Y., Imani, V., Saffari, M., Griffiths, M. D., \& Pakpour, A. H. (2020). The Fear of COVID-19 Scale: Development and Initial Validation. International Journal of Mental Health and Addiction. https://doi.org/10.1007/s11469-020-00270-8

Armitage, R., \& Nellums, L. B. (2020). COVID-19 and the consequences of isolating the elderly. The Lancet Public Health, 5(5), e256. https:// doi.org/10.1016/S2468-2667(20)30061-X

Bartel, M. (2020). Alkohol: Verkauf in Corona-Krise gestiegen - „Sorgen befördern Konsum“. https://rp-online.de/panorama/coronavirus/ alkohol-verkauf-in-corona-krise-gestiegen-sorgen-befoerdern-konsum_aid-50137939

Baumeister, H., \& Montag, C. (Eds.). (2019). Digital Phenotyping and Mobile Sensing: New Developments in Psychoinformatics. Springer International Publishing. https://doi.org/10.1007/978-3-030-31620-4

Chinazzi, M., Davis, J. T., Ajelli, M., Gioannini, C., Litvinova, M., Merler, S., Piontti, A. P. y, Mu, K., Rossi, L., Sun, K., Viboud, C., Xiong, X., Yu, H., Halloran, M. E., Longini, I. M., \& Vespignani, A. (2020). The effect of travel restrictions on the spread of the 2019 novel coronavirus (COVID-19) outbreak. Science, 368(6489), 395-400. https:// doi.org/10.1126/science.aba9757

Cho, H., Ippolito, D., \& Yu, Y. W. (2020). Contact Tracing Mobile Apps for COVID-19: Privacy Considerations and Related Trade-offs. ArXiv:2003.11511 [Cs]. http://arxiv.org/abs/2003.11511

Clay, J. M., \& Parker, M. O. (2020). Alcohol use and misuse during the COVID-19 pandemic: A potential public health crisis? The Lancet Public Health, 5(5), e259. https://doi.org/10.1016/S24682667(20)30088-8

Coibion, O., Gorodnichenko, Y., \& Weber, M. (2020). Labor Markets During the COVID-19 Crisis: A Preliminary View (Working Paper No. 27017; Working Paper Series). National Bureau of Economic Research. https://doi.org/10.3386/w27017

Dagum, P. (2018). Digital biomarkers of cognitive function. Npj Digital Medicine, 1(1), 1-3. https://doi.org/10.1038/s41746-018-0018-4

Dagum, P., \& Montag, C. (2019). Ethical Considerations of Digital Phenotyping from the Perspective of a Healthcare Practitioner. In H. Baumeister \& C. Montag (Eds.), Digital Phenotyping and Mobile Sensing: New Developments in Psychoinformatics (pp. 13-28). Springer International Publishing. https://doi.org/10.1007/978-3030-31620-4_2

Hurtz, S. (2020, April 1). Pepp-PT vs. Covid-19: Diese App soll das Virus stoppen - Digital - SZ.de. https://www.sueddeutsche.de/digital/ coronavirus-smartphone-app-handy-tracing-pepp-pt-1.4865199

Ienca, M., \& Vayena, E. (2020). On the responsible use of digital data to tackle the COVID-19 pandemic. Nature Medicine, 26(4), 463-464. https://doi.org/10.1038/s41591-020-0832-5

Insel, T. R. (2017). Digital Phenotyping: Technology for a New Science of Behavior. JAMA, 318(13), 1215-1216. https://doi.org/10.1001/ jama.2017.11295

Insel, T. R. (2018). Digital phenotyping: A global tool for psychiatry. World Psychiatry: Official Journal of the World Psychiatric Association (WPA), 17(3), 276-277. https://doi.org/10.1002/wps.20550

Király, O., Potenza, M. N., Stein, D. J., King, D. L., Hodgins, D. C., Saunders, J. B., Griffiths, M. D., Gjoneska, B., Billieux, J., Brand, M., Abbott, M. W., Chamberlain, S. R., Corazza, O., Burkauskas, J., Sales, C. M. D., Montag, C., Lochner, C., Grünblatt, E., Wegmann, E., ... Demetrovics, Z. (2020). Preventing problematic internet use during the COVID-19 pandemic: Consensus guidance. Com- 
prehensive Psychiatry, 100, 152180. https://doi.org/10.1016/j.comp psych.2020.152180

Lurie, N., Saville, M., Hatchett, R., \& Halton, J. (2020). Developing Covid-19 Vaccines at Pandemic Speed. New England Journal of Medicine, 382, 1969-1973. https://doi.org/10.1056/NEJMp2005630

Mamun, M. A., \& Griffiths, M. D. (2020). First COVID-19 suicide case in Bangladesh due to fear of COVID-19 and xenophobia: Possible suicide prevention strategies. Asian Journal of Psychiatry, 51, 102073. https://doi.org/10.1016/j.ajp.2020.102073

Martinez-Martin, N., Insel, T., Dagum, P., Greely, H., \& Cho, M. (2018). Data mining for health: Staking out the ethical territory of digital phenotyping. Npj Digital Medicine, 68. https://doi.org/10.1038/ s41746-018-0075-8

Matthay, M. A., Aldrich, J. M., \& Gotts, J. E. (2020). Treatment for severe acute respiratory distress syndrome from COVID-19. The Lancet Respiratory Medicine, 8(5), 433-434. https://doi.org/10.1016/S2213$2600(20) 30127-2$

Mayor, S. (2020). Covid-19: Researchers launch app to track spread of symptoms in the UK. BMJ, 368. https://doi.org/10.1136/bmj.m1263

McCall, B. (2020). COVID-19 and artificial intelligence: Protecting health-care workers and curbing the spread. The Lancet Digital Health, 2(4), e166-e167. https://doi.org/10.1016/\$2589-7500 (20)30054-6

Mehta, P., McAuley, D. F., Brown, M., Sanchez, E., Tattersall, R. S., \& Manson, J. J. (2020). COVID-19: Consider cytokine storm syndromes and immunosuppression. The Lancet, 395(10229), 10331034. https://doi.org/10.1016/S0140-6736(20)30628-0

Messner, E.-M., Sariyska, R., Mayer, B., Montag, C., Kannen, C., Schwerdtfeger, A., \& Baumeister, H. (2019). Insights - Future Implications of Passive Smartphone Sensing in the Therapeutic Context. Verhaltenstherapie. https://doi.org/10.1159/000501951

Montag, C., Baumeister, H., Kannen, C., Sariyska, R., Meßner, E.-M., \& Brand, M. (2019). Concept, Possibilities and Pilot-Testing of a New Smartphone Application for the Social and Life Sciences to Study Human Behavior Including Validation Data from Personality Psychology. J - Multidisciplinary Scientific Journal, 2(2), 102-115. https://doi.org/10.3390/j2020008

Montag, C., Błaszkiewicz, K., Lachmann, B., Andone, I., Sariyska, R., Trendafilov, B., Reuter, M., \& Markowetz, A. (2014). Correlating Personality and Actual Phone Usage. Journal of Individual Differences, 35(3), 158-165. https://doi.org/10.1027/1614-0001/a000139

Montag, C., Sindermann, C., \& Baumeister, H. (2020). Digital phenotyping in psychological and medical sciences: A reflection about necessary prerequisites to reduce harm and increase benefits. Current Opinion in Psychology, 36, 19-24. https://doi.org/10.1016/j.copsyc. 2020.03.013

Oliver, N., Letouzé, E., Sterly, H., Delataille, S., De Nadai, M., Lepri, B., Lambiotte, R., Benjamins, R., Cattuto, C., Colizza, V., de Cordes, N., Fraiberger, S. P., Koebe, T., Lehmann, S., Murillo, J., Pentland, A., Pham, P. N., Pivetta, F., Salah, A. A., ... Vinck, P. (2020). Mobile phone data and COVID-19: Missing an opportunity? ArXiv:2003.12347 [Cs]. http://arxiv.org/abs/2003.12347

Qiu, J., Shen, B., Zhao, M., Wang, Z., Xie, B., \& Xu, Y. (2020). A nationwide survey of psychological distress among Chinese people in the COVID-19 epidemic: Implications and policy recommendations. General Psychiatry, 33(2), e100213. https://doi.org/10.1136/gpsych2020-100213
Rosenbach, M., Rosenfelder, L., Schmergal, C., Schmundt, H., \& Wiedmann-Schmidt, W. (2020, May 2). Kein Allheilmittel. Der Spiegel.

Saeb, S., Lattie, E. G., Kording, K. P., \& Mohr, D. C. (2017). Mobile Phone Detection of Semantic Location and Its Relationship to Depression and Anxiety. JMIR MHealth and UHealth, 5(8), e112. https://doi.org/10.2196/mhealth.7297

Saeb, S., Zhang, M., Karr, C. J., Schueller, S. M., Corden, M. E., Kording, K. P., \& Mohr, D. C. (2015). Mobile Phone Sensor Correlates of Depressive Symptom Severity in Daily-Life Behavior: An Exploratory Study. Journal of Medical Internet Research, 17(7), e175. https://doi. org/10.2196/jmir.4273

Schimmenti, A., Billieux, J., \& Starcevic, V. (2020). The four horsemen of fear: An integrated model of understanding fear experiences during the COVID-19 pandemic. Clinical Neuropsychiatry, 17(2), 41-45.

Zuboff, S. (2019). The Age of Surveillance Capitalism: The Fight for a Human Future at the New Frontier of Power: Barack Obama's Books of 2019. Profile Books.

Zulueta, J., Piscitello, A., Rasic, M., Easter, R., Babu, P., Langenecker, S. A., McInnis, M., Ajilore, O., Nelson, P. C., Ryan, K., \& Leow, A. (2018). Predicting Mood Disturbance Severity with Mobile Phone Keystroke Metadata: A BiAffect Digital Phenotyping Study. Journal of Medical Internet Research, 20(7), e241. https://doi.org/10.2196/ jmir.9775

\section{${ }^{*}$ Corresponding author}

\section{Prof. Dr. Christian Montag}

Institute for Psychology and Education

Helmholtzstr. 8/1

Ulm University

89081 Ulm, Germany

Tel.: +49-731-50-26550

Fax: +49-731-50 32759

E-Mail: christian.montag@uni-ulm.de

\section{Conflict of Interest}

None. Nevertheless, for reasons of transparency, it is mentioned that Christian Montag is currently funded by Mindstrong Health to carry out a project on digital phenotyping and mental disorders. Paul Dagum is the founder of Mindstrong Health and owns stock in Mindstrong Health, a company focusing on digital phenotyping. Outside the scope of the present paper, Dr. Elhai notes that he receives royalties for several books published on posttraumatic stress disorder (PTSD); is a paid, fulltime faculty member at University of Toledo; is a paid, visiting scientist at Tianjin Normal University; occasionally serves as a paid, expert witness on PTSD legal cases; and receives grant research funding from the U.S. National Institutes of Health.

\section{Funding}

None. 